\title{
The Formulation of Employee Selection Format, Compilation of Job Description, and Compilation of Performance Appraisal on JEE Ballroom Group \& Exhibitor
}

\author{
Lukmanul Hakim ${ }^{1, *}$
}

\author{
${ }^{1}$ Universitas Indonesia \\ *Corresponding author.Email: lukmanluki10@gmail.com
}

\begin{abstract}
This study is in the form of business coaching carried out in the SMEs JEE Ballroom Group \& Exhibitor. There are some disadvantages to the management of human resources that currently exist. The objective of implementing this business coaching is to develop the process of human resources, which causes employee performance is not as expected. This study will focus on the formulation of a selection format, a compilation of job descriptions, and a compilation of performance appraisal system. It is expected that this business coaching can help the JEE Ballroom Group \& Exhibitor in improving its performance
\end{abstract}

Keywords: Employee Selection Format, Compilation of Job Description, Compilation of Performance Appraisal.

\section{INTRODUCTION}

MICE (Meeting, Incentive, Convention, and Exhibition) is one of the currently developing industries. The MICE industry's prospect is compelling in the era of globalization with the development of technology, science, and the business's development, which leads to a meeting, negotiations, both on a na-tional or international scale. Besides MICE, the wedding industry is one of the promising industries, especially in meeting room rental. This is because of the limited choice of meeting hall that currently available and the high public interest. Based on the survey carried out by Bridestory, $40-60 \%$ of the total budget spent for a wedding is used for the venue and catering, and most of them still choose a meeting room as a wedding venue [1].

Although this industry is quite impressive, it does not escape from SMEs' problems in general. According to reference [2], SMEs is faced with several problems:

- Weaknesses in expanding market share and market opportunities

- Weaknesses in the sector of organization and limitation in the source of capital
- Weaknesses in the sector of organization and the management of human resources

- $\quad$ Limitation of the business network

- $\quad$ Competitive business environment

Management of human resources is one of the problems faced by SMEs. As for the human resources faced by the SMEs, among others are (1) difficulties in hiring employees, (2) setting rules, (3) directing to the same destination or goals, (4) devel-oping employee competencies, (5) assessing em-ployee performance, (6) determining reward \& pun-ishment (7) overcoming financial limitations, (8) facing employee demands, (9) retain employees, (10) terminating employees.

One of the SMEs involved in the MICE industry and wedding is PT Anugrah Puri Pertiwi, with a JEE Ballroom Group \& Exhibitor business name. JEE Ballroom Group \& Exhibitor founded by Rika Pertiwi Zulfi as the Managing Director. For the business itself, in addition to providing building, JEE Ballroom Group \& Exhibitor also provides wedding package which offered to the consumers. In the future, JEE Ballroom Group \& Exhibitor will carry out business development 
by adding the number of management of the meeting room.

Some problems exist in the JEE Ballroom Group \& Exhibitor based on the data analysis from the results of an interview with Rika Pertiwi Zulfi as the business owner. First, JEE Ballroom Group \& Exhibitor experience difficulties in selecting prospective employees that are under company expectations. This can be seen from the number of employees ousted or terminated because it does not meet the company's expectations and come from the company's goal that wants to expand their business by adding the meeting room. Then it needs the addition of new human resources. So, the standard employee selection format needs to be applied.

Second, the JEE Ballroom Group \& Exhibitor currently does not have a standard job description, so the employees have difficulty in understanding the task and responsibilities that must be done. So, the employees often carry out their initiatives in doing their job. Third, currently, the company sees the employee performance only in marketing division employees by looking at how much sales the employee can do. However, for other divisions, the performance has not yet been measured, so the reward is only given to the marketing division's sales performance. Therefore, the assessment of employee performance needs to be implemented so that each employee gets the opportunity to get an appraisal in the future. This employee performance evaluation later will also help in improving performance and become a tool to motivate the employees [3].

\subsection{Theoretical framework}

\subsubsection{The process HR strategy}

Reference [4] explain the process of human resources strategies which is started from the company's mission and formulating the goals to be achieved. After that, external and internal analysis is carried out to see opportunities and threats as well as the strengths and weaknesses of the company. Based on the analysis, the strategies used to achieve these objectives are determined. Fig. 1. Show process of HR strategy.
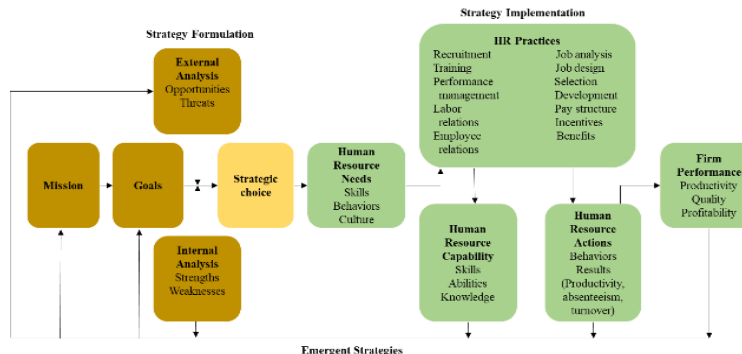

Figure 1 Process of Human Resource Strategy
To carry out this strategy, there is a need for hu-man resources. To implement this strategy, it is necessary to practice human resources, which will produce two outputs, namely human resource capability and human resource action. From human resource action, it will produce firm performance.

\subsubsection{Selection}

Recruitment and selection are one of the vital functions of human resource management for various types of businesses. Effective selection and recruitment practices can generate positive human resources and produce a good company performance [5]. One of the most widely used selection methods is an interview. Some researchers report that compared to other selection methods, interviews are the method most widely used as the main consideration in the making process of recruitment decision [6]. Interview selection is a procedure designed to predict job performance in the future based on applicants' verbal responses to a given question [7]. The interview tech-nique used is the STAR method (Situation, Task, Action, Results) [8]. This method is in the behavioral interview category. The behavioral interview is a series of questions related to work that focus on how candidates react to the actual situation in the past [7].

\subsubsection{Job description}

Before compiling the job description, some steps must be done, namely to do a thorough job analysis. Job analysis is a procedure for determining the tasks and expertise needed for a job and what kind of per-son must be employed for this job [7]. After doing a job analysis, a job description will appear, resulting from a more detailed job analysis. In contrast, the job specification is a list of requirements that a person must meet, such as education [7]. A job description is a list of tasks, obligations, and responsibilities required for a job [4]. A job description is a document that is ideally first given by the company to all employees [9].

The job description also functions as a means of employee performance appraisal, which can be seen whether the employee meets the performance as specified in the job description. Job descriptions need to be written broadly and structurally, making it easier for the employees to determine important tasks [4]. Reference [10] explains some of the strengths that can be utilized from job descriptions, including job descriptions that can help employees develop their jobs in the company. Job descriptions can also be used as question material in carrying out interviews with candidates; companies can evaluate candidates' level of knowledge, specifically on the position offered. 


\subsubsection{Performance appraisal}

Performance management is a process in which the activity is conducted, and the result given by an employee is under the company's goal. Through performance management, the company can obtain a competitive advantage [4]. Performance management can also be used as an approach in the development and man-agement of human resources to enhance the company's short-term and long-term targets [11]. according to [3], the application of performance management has ad-vantages as follow: (1) become objective, accurate and transparent toward achievement business target and employee performance, (2) as means of communication and management tool to improve organization performance from various aspects including aspects of finance, operational and human resource, (3) as a tool to motivate the employee in order to give the best performance and as as a basis for awarding employees, (4) As reference material for preparing employee development programs.

One form of performance management is performance appraisal or individual performance appraisal, a system used to evaluate individual performance in a given period and provide feedback and individual development for each employee. Thus, their performance can continue to be improved [11]. The increase in performance in individuals will affect the performance of the company.

Refenrence [12] explain the process of performance appraisal. The first process that needs to be conducted is to identify the specific goals that the company wants to achieve. Company management needs to determine the most critical goals and can be achieved realistically. The next step is to set standards for performance criteria and communicate these standards to the employees concerned. Then the employee runs the job, and the performance of the employee will be given an assessment.

This performance appraisal can help determine how a good employee has met applied performance standards, determine the reasons for the shortcomings, and develop plans to correct these deficiencies. Based on reference [7], performance appraisal will be more effective if the superior first explains the employee's job criteria and performance.

\section{METHODS}

There were eight program sessions of business coaching conducted by JEE Ballroom Group \& Exhibitor. The first session began on 4 October 2018, at the campus of the University of Indonesia's Master of Management, where the coach introduced himself and the owner introduced a business profile and an overview of the JEE Ballroom Group \& Exhibitor. The second to the fifth session were conducted from November 2018 to February 2019 to analyze its business conditions and identify the problems. The sixth to eighth sessions had been conducted from March to May 2019 to implement solutions based on identified problems.

\subsection{Research subject}

The subject of this research was UMKM PT Anugerah Puri Pertiwi, named JEE Ballroom Group \& Exhibitor business. JEE Ballroom Group \& Exhibitor was founded by Rika Pertiwi Zulfi as Managing Director. The JEE Ballroom Group \& Exhibitor head office is located in Grand Galaxy Park, where the office is integrated into one of the meetinghouses owned by JEE Ballroom Group \& Exhibitor. This research's primary source was the owner and several employees of the JEE Ballroom Group \& Exhibitor.

\subsection{Methods of collecting the data}

Techniques of collecting the data in the business coaching process were qualitative, focusing on the company, business problems, and the factors causing the problem both internally and externally would be investigated by various types of analysis. Data collected consists of two types of data such as primary data and secondary data. Primary data is data obtained through direct interaction with the object of research. In this case, It was JEE Ballroom Group \& Exhibitor. There were two methods used to collect primary data, such as indepth interviews and observations.

An interview would be conducted with Rika as the JEE Ballroom Group \& Exhibitor owner to give questions related to the overall JEE Ballroom Group \& Exhibitor business. In addition, interviews were also conducted with Fera as general admin related to HR issues and management in the company. The results of this interview would be part of the process of identifying company problems. The secondmary data collection method was the observation, which was very useful to see the company's condition directly. Observation also eased to identify the problems.

In collecting secondary data, literature studies were conducted to get information and knowledge about business and get the best problem-solving solutions. Literature studies were obtained from various sources such as scientific articles, journals, books, and other sources.

\subsection{Method of Analyzing Data}

Data collected would be analyzed using some tools: business model canvas, PESTEL, competitor analysis, market opportunity analysis, marketing mix (7P), and SWOT analysis. After conducting the analysis, the final 
step was to conclude all data obtained. Conclusions were obtained by understanding the data which has been presented and used as information for business coaching purposes.

Business model canvas is a business model approach presented in a canvas sheet with nine parts: key partners, key activities, key resources, value propositions, customer relationships, channels, customers segment, cost structure, and revenue streams. The canvas business model aims to make everyone understand the business's direction and objectives, and the canvas model business can easily describe a business model as a new alternative strategy.

PESTEL Analysis, one of the tools that can be used to understand external factors that impacted the company is PESTEL Analysis. There are six factors in PESTEL analysis such as Political, Economic, Social, Technological, Environmental, Legal [13].

Competitor Analysis, Analysis of five forces is to analyze competition in the industry. The nature and the ins and outs of competition in each industry differ from each other and need to be fully understood to accurately assess the company's current situation [13]. There are five factors used to identify and evaluate potential business opportunities and risks that later will be a threat of new entrants, the threat of substitutes, bargaining power of suppliers, bargaining power of customers, competitive rivalry.

Marketing mix 7P, While developing the market strategy for manufactured goods, ordinary marketers refer to the basic $4 \mathrm{P}$ strategy such as product, price, place, and promotion. However, this $4 \mathrm{P}$ strategy is insufficient to deal with problems arising in marketing services and must be adjusted and expanded [14]. Therefore, the $4 \mathrm{P}$ marketing mix needs to be expanded by adding three things related to service delivery: the process, physical environment, and people.

SWOT analysis and TOWS matrix, SWOT analysis is a simple tool, but it is advantageous to measure its internal strength, lack of competitiveness, opportunities in the market, and external threats that can affect the company's sustainability [13]. This analysis consists of four elements, such as strength, weakness, opportunity, and threat. Based on the SWOT analysis results, the TOWS matrix can then be used to deduce strategies that can be applied to find a competitive advantage.3. Results and Discussion

\subsection{Questionnaire result}

From the 174 distributed questionnaires, 138 respondents passed the screening and completed the questionnaire $(85.71 \%)$.

\subsection{Descriptive analysis}

Table 2. Descriptive analysis result

\begin{tabular}{|c|c|}
\hline Indicator & Mean \\
\hline SHARED1 & 4.70 \\
\hline SHARED2 & 4.67 \\
\hline SHARED3 & 4.65 \\
\hline SOCIAL1 & 4.63 \\
\hline SOCIAL2 & 4.25 \\
\hline SOCIAL3 & 4.43 \\
\hline VOICE1 & 4.41 \\
\hline VOICE2 & 4.60 \\
\hline VOICE3 & 4.78 \\
\hline VOICE4 & 4.33 \\
\hline LEADER1 & 4.36 \\
\hline LEADER2 & 4.43 \\
\hline LEADER3 & 4.27 \\
\hline LEADER4 & 4.12 \\
\hline LEADER5 & 4.61 \\
\hline LEADER6 & 4.38 \\
\hline LEADER7 & 4.30 \\
\hline LEADER8 & 4.23 \\
\hline LEADER9 & 4.20 \\
\hline LEADER10 & 4.52 \\
\hline COHESION1 & 4.54 \\
\hline COHESION2 & 4.57 \\
\hline COHESION3 & 4.56 \\
\hline COHESION4 & 4.48 \\
\hline COHESION5 & 4.68 \\
\hline OUT1 & 4.39 \\
\hline OUT2 & 4.39 \\
\hline OUT3 & 3.98 \\
\hline OUT4 & 4.42 \\
\hline OUT5 & 4.10 \\
\hline QUAL1 & 4.66 \\
\hline QUAL2 & 4.65 \\
\hline QUAL3 & 4.61 \\
\hline ORGPL1 & 4.55 \\
\hline ORGPL2 & 4.54 \\
\hline ORGPL3 & 4.05 \\
\hline ORGPL4 & 4.05 \\
\hline INTER1 & 4.71 \\
\hline INTER2 & 4.56 \\
\hline INTER4 & 4.64 \\
\hline VALUE1 & 4.06 \\
\hline VALUE2 & 4.63 \\
\hline VALUE3 & 4.13 \\
\hline ALL1 & 4.34 \\
\hline ALL2 & 4.50 \\
\hline ALL3 & 4.46 \\
\hline ALL4 & 4.51 \\
\hline
\end{tabular}

\subsection{Hypotheses test}

Table 3 Show hypotheses result.

\begin{tabular}{|c|lr|l|l|l|l|}
\hline $\begin{array}{c}\text { Cod } \\
\text { e }\end{array}$ & \multicolumn{2}{|c|}{$\begin{array}{l}\text { Hypothese } \\
\text { s }\end{array}$} & $\begin{array}{c}\text { Estimat } \\
\mathbf{e}\end{array}$ & $\begin{array}{c}\text { CR } \\
\text { (T- }\end{array}$ & $\begin{array}{c}\text { Cod } \\
\mathbf{e}\end{array}$ & $\begin{array}{c}\text { Hypothese } \\
\text { s }\end{array}$ \\
\hline H1 & LEA & & 0.975 & 8.57 & $* * *$ & Accept \\
& $\begin{array}{l}<-- \\
\text { ENV }\end{array}$ & & & 2 & & \\
\hline H2 & CO & $<---$ & 0.975 & 8.57 & $* * *$ & Accept \\
& ENV & & & 2 & & \\
\hline H3 & CFT & $<---$ & 0.950 & 9.60 & $* * *$ & Reject \\
& LEA & & & 9 & & \\
\hline H4 & CFT & $<---$ & -0.088 & -0.29 & 0.772 & Accept \\
& CO & & & & & \\
\hline H5 & CFT & $<-$ & 0.317 & 2.02 & 0.043 & Accept \\
& --ENV & & 7 & & \\
\hline H6 & CFT & $<---$ & 0.765 & 2.05 & 0.04 & Reject \\
\hline
\end{tabular}




\begin{tabular}{|l|l|l|l|l|l|} 
& $\begin{array}{l}\text { LEA } \\
<-- \text { ENV }\end{array}$ & & 4 & & \\
\hline H7 & CFT & -0.086 & & & Accept \\
& $\begin{array}{l}\text { CO } \\
\text { CO }\end{array}$ & & & & \\
& -- ENV & & & & \\
\hline
\end{tabular}

For a hypothesis to be accepted, the CR (T-value) score must be above 1.645, while the p-value must be smaller than 0.05 . To find the model's indirect effect value, the researcher used a formulation from Sobel, an equivalent approach that calculates the indirect by multiplying two regression coefficients. From the 7 hypotheses, 2 hypotheses were rejected, which are $\mathrm{H} 3$ and H6.

\subsection{Finding and implementation}

A. Finding of analysis

1) Business model canvas

Based on BMC analysis, the figure below shows the business model canvas in JEE Ballroom Group \& Exhibitor. Fig. 2. Show business model camvas JEE Ballroom Group and exhibitor.

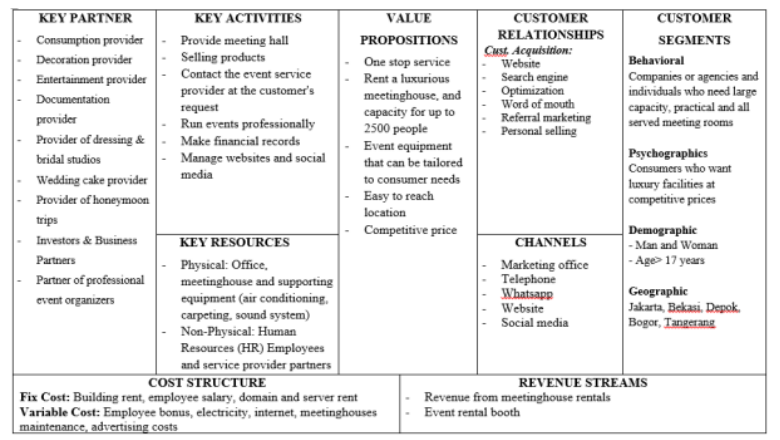

Figure 2 . Business Model Canvas JEE Ballroom Group \& Exhibitor

To maintain and increase the value proposition that already has a company, JEE Ballroom Group \& Exhibitor needs to optimize key activities related to evaluating human resources by implementing employee performance appraisals.

\section{2) PESTEL Analysis}

In economic terms with the dynamic economic growth rate of Bekasi City has enhanced people's purchasing power. It has become an opportunity for the JEE Ballroom group \& exhibitor. On social factors with an increase in the number of marriages, Bekasi city can be the company's opportunity. In terms of human resource management, the working-age is now beginning to be dominated by millennial generations. Millennial is a generation with low loyalty to the company, which causes high turnover which is a challenge for companies to keep their best employees to remain loyal to the company. Techno-logical Factors that are developing rapidly now be-come opportunities to ease the company's marketing activities to be better known for its products by prospective consumers. Furthermore, on environmental factors, with the limited number of meetinghouses in the City of Bekasi, it can be an opportunity for the JEE Ballroom Group \& Exhibitor to cover the mar-ket share of Bekasi City wedding buildings.

Meanwhile, the threats faced are politics and law, both of which are related to regulations that have been set by the government, which can weigh the company. In politics, the maximum stipulation of annual income to get tax deductions cannot be felt by the JEE Ballroom Group \& Exhibitor, which causes the company to have a considerable burden in paying taxes. Whereas in legal factors, the application of high UMK causes high costs for the company's employee salaries.

\section{3) Competitor Analysis}

The threat of the new entrants' category is low since the high capital is needed to enter this industry. The bargaining power of suppliers is also low due to the vast selection of event support suppliers, and the bargaining power of consumers is also relatively small because of the limited number of currently available meetinghouses. However, the threat is in the category of substitute products that replace the role of meetinghouses and fellow competitors who offer competitive offers to each other. Therefore, JEE Ballroom Group \& Exhibitor must highlight its superiority to capture the opportunities that exist.

4) Marketing mix 7P

There are aspects of the JEE marketing mix Ballroom Group \& Exhibitor, which is still an obstacle that can hamper business continuity. In terms of people, the number of human resources currently lacks essential positions such as Marketing Managers, and the current financial position is filled with inexperienced people so that current financial records are not following the accounting standards. In terms of the process, HR has not yet run the employee management, such as making a standard job description because employees do not have guidelines in carrying out their duties and responsibilities. 


\section{5) SWOT analysis and TOWS analysis}

Fig. 3. Describes the TOWS matrix in the JEE Ballroom Group \& Exhibitor based on the SWOT analysis.

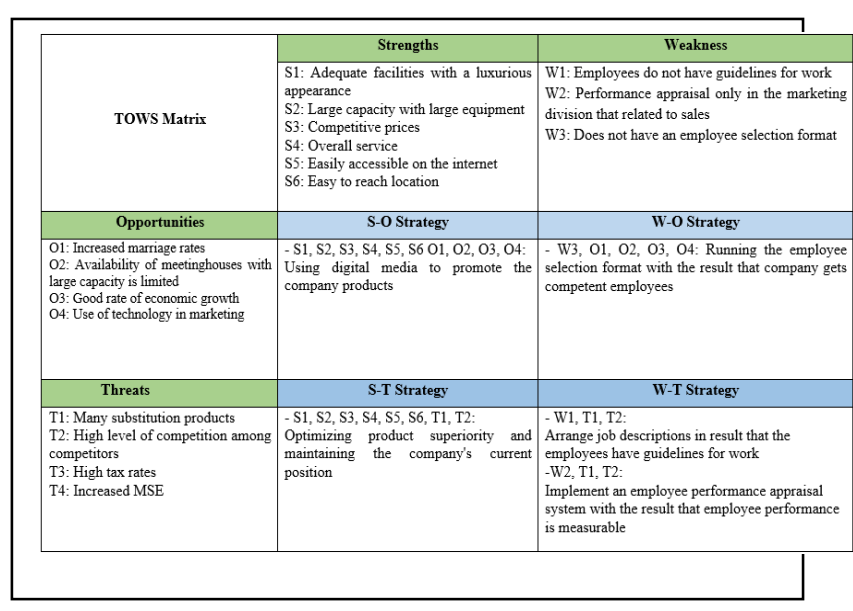

Figure 3. TOWS JEE Ballroom Group \& Exhibitor Matrix

Based on the TOWS matrix, the solution that can be implemented by the JEE Ballroom Group \& Exhibitor is $\mathrm{W} 3, \mathrm{O} 1, \mathrm{O} 2, \mathrm{O} 3, \mathrm{O} 4$, which is to run the employee selection format in a result that the company gets competent employees following the company's goal of developing its business. The next so-lution is $\mathrm{W} 1, \mathrm{~T} 1$, $\mathrm{T} 2$, which compiling a job description so that employees have guidelines in work. The last is $\mathrm{W} 2, \mathrm{~T} 1, \mathrm{~T} 2$, which implement an employee performance appraisal system so as employee's division can be monitored for performance.

\section{B. Implementation of solutions \\ 1) Selection}

Based on the company's goals that want to develop its business and be seen from the competence of existing employees, the coach suggests using the interview method in conducting the selection. One way that can be used in interviews is STAR. The STAR method is related to behavioral interviews, namely giving a series of workrelated questions that focus on how the candidate reacts to the actual situation in the past [7]. Previously JEE Ballroom Group \& Exhibitor did not have guidelines in terms of interviewing candidates for employees. Here, the coach provides a list of questions that can be used with the STAR method, and this list of items can dig deeper into leadership, planning ability, interaction, decision making. After that, the next step is to evaluate the candidates' interview results by writing down how the candidates responded to the answers during the interview. Interviews are considered more structured when notes are taken when the candidate responds during the interview rather than writing notes after it [15]. Tabel 3. Show interview questions list.
Table 3. Interview questions list

Employee candidates based on functions inter-view questions list Planning and drafting abilities

1 Describe specifically the situations where you set a way to achieve goals.

2 Tell me how when you have to choose between two or more critical opportunities. How you determine which opportunities are most important to you.

3 How do you usually manage your time to complete your daily tasks?

4 Share the situation where you have a significant role in organizing important events. How you do it.

5 Give examples of how you compile notes and material to learn essential tests.

6 Explain when you rearrange something to be more efficient. How you do it.

7 Think of a time when you made a vital plan and became chaotic. How you react and what you do.

\section{2) Job description}

Compiling the job descriptions is conducted in three stages. The first is data collection. The coach collects data on what is needed, what competencies must be owned, and each job's scope in the JEE Ballroom Group \& Exhibitor. Next is the drafting stage. The authors compile the data collected to get the main ideas about the description of the work on the JEE Ballroom Group \& Exhibitor and arrange the appropriate job descriptions. The final stage in the preparation of job descriptions is validation, where the coach confirms the job description that has been prepared for the company. This stage is conducted so that the job description has been prepared under the company's conditions. The contents that exist in the job description include the name of the employee, position, related supervisor, related subordinates, job specifications, duties, and responsibilities.

\section{3) Performance Appraisal}

In evaluating individual performance, determining performance indicators is based on two perspectives, namely the operational perspective of the company and the competency perspective. Based on the company's operational perspective, individual performance indicators reflect the scope of work carried out daily by employees. Based on the competency perspective, individual performance indicators include aspects related to the employee's personality in carrying out the job. This aspect consists of honesty and integrity, motivation and willingness to achieve, discipline, cooperation, and communication skills. The assessment of this aspect of competency applies equally to each position. The preparation of individual performance assessment indicators is related to the assessment of work objectives, based on the results of work analysis, resulting in job descriptions. The assessments on aspects of the work target have the most significant weighting value of $70 \%$. 
In contrast, the assessment of competency aspects has a smaller weighting value of $30 \%$. The application of individual performance assessments is carried out periodically within a specific interval of time. This assessment can be done within one year or once every six months.

\section{CONCLUSIONS}

A selection format has been created by compiling a list of questions that will be asked to the prospective employees. In addition, the STAR interview method is used to dig deeper into the employee candidates. The prospective employee evaluation form is made so that the interviewer can make a documented assessment, and what aspects need to be assessed are contained in the potential employee's evaluation form. The owner feels that the existence of this format selection makes it easier to make prospective employees selection, seeing from the company's plans to develop their business so that it requires the addition of human resources.

The preparation of job descriptions begins with conducting a job analysis. Job analysis is carried out by indepth interviews with the company owner and several employees to explore the duties and responsibilities and the competencies needed in a position that has been carried out. The formulated job de-scription consists of eight positions: Main Director, General Director, Finance Director, Marketing Man-ager, Sales, General Admin, Finance, and Operations Admin. With this job description, employees better understand the duties and responsibilities, and work goals that must be achieved, and it has a function as an indicator in conducting performance assessments.

The preparation of individual performance assessments has been carried out by determining the weight in each aspect of the assessment. There are two aspects assessed, namely aspects of the work target and aspects of the competency target. The indicators on aspects of the work target are obtained from the job descriptions of each position. Mean-while, the competency aspect indicator consists of four indicators: honesty and integrity, attendance, willingness to achieve, cooperation, and communication skills. Each position has the same indicator of competency aspects.

\section{ACKNOWLEDGMENT}

The author would like to thank Ir. Hasnul Suhaimi, MBA as the supervisor, and Dr. Lily Sudhartio and Sisdjiatmo K Widhaningrat, M.SC as the examiners. This research is supported by the University of Indonesia's Master of Management program.

\section{REFERENCES}

[1] Indonesian wedding trend reports. Bridestory. January 28, 2019. [Online]. Avaible: https://www.bridestory.com/id/blog/2017indonesia-wedding-trends-report-by-bridestory

[2] M. Kuncoro, Masalah Kebijakan dan Politik Ekonomika Pembangunan. Jakarta: Erlangga. 2010 .

[3] A.T. Soemohadiwidjojo , SOP dan KPI untuk UMKM \& Startup. Jakarta: Raih Asa Sukses. 2018.

[4] Noe, Hollenbeck, Gerhart and Wright. Human Resource Management, 9th Ed. New York, NY: McGraw-Hill Education, 2015.

[5] A.S. Gamage, "Recruitment and selection practices in manufacturing smes in japan: an analysis of the link with business performance," Ruhuna J. Manag. Financ., 2014.

[6] A.J. Kinicki, C. A. Lockwood, P. W. Hom, and R. W. Griffeth, "Interviewer Predictions of Applicant Qualifications and Interviewer Validity: Aggregate and Individual Analyses,” J. Appl. Psychol., 1990.

[7] Dessler, Human Resource Management, 15th Ed, Harlow: Pearson Education, 2017.

[8] STAR Method. caseinterview.com. March 5, 2019. [Online]. https://www.caseinterview.com/star-method/

[9] B.S.G. Pató, "Formal options for job descriptions: theory meets practice,” J. Manag. Dev., 2017

[10] S. Leon Rohr, "Harnessing the power of the job description," Hum. Resour. Manag. Int. Dig., 2016.

[11] N. Herachwati, "Performance aprasial," J. Ekon. dan Bisnis, 2013.

[12] R. Wayne Dean Mondy and J. Joseph Martocchio, Human resource management, Global Ed, 2016.

[13] A.A.J. Thompson, A.J.I. Strickland, and J.E. Gamble, Crafting \& executing strategy - the quest for competitive advantage. 2018.

[14] Wirtz, Jochen and Lovelock, Christoper, Service marketing: people technology strategy, Hackensack: World Scientific Publishing, 2016.

[15] Simola, Taggar and Smith, "The employment selection interview: disparity among researchbased recommendations, current practices and what matters to human rights tribunals," Canadian J. Administrative Sciences., vol. 24, no. 1, pp. 30 , 2007. 